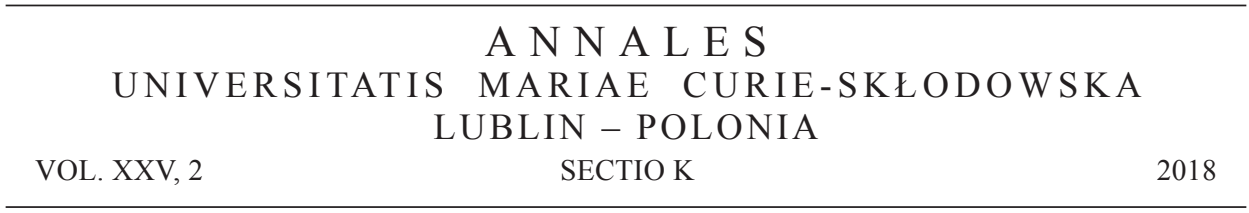

Jagiellonian University in Kraków. Faculty of International and Political Studies

\author{
NATALIA STRĘK
}

ORCID ID: https://orcid.org/0000-0003-0484-3868

\title{
The Idea of Situational Leadership in Political Parties
}

\begin{abstract}
The results of the Polish parliamentary elections in 2015 showed a significant change in the behaviour of the electorate. Two completely new political groups have entered the Sejm. For the very first time in the history of the Third Polish Republic, a new balance of power emerged, which excluded the left-wing parties from political discourse without assigning them a parliamentary mandate [Dudek 2016: 687]. In the face of this turn of events, it is difficult to maintain the thesis concerning the "freezing" of the circulation of political elites in the current political system. The Modern political party was established on 31 May 2015 [Kim jesteśmy?], while the Kukiz'15 political movement formed only three months before the parliamentary elections [O stowarzyszeniu - wtadze krajowe i okregowe]. These two political organizations were able to overcome the electoral threshold and achieve unexpected success in such a short period of time and without an extensive party structure or significant financial base. The mobilisation of the electorate took place outside the parliamentary structures. In view of this, is the phenomenon of "over-parlamentisation" [Żukiewicz 2011: 343] involved in the creation of political leaders still valid? Is it to be believed, that in the face of ever more frequent grassroots social initiatives, the real political struggle still only takes place within the parties and political leaders who are not traditional participants of political party games but who appear as activists associated with other areas of public life?

On the other hand, the changes that take place in the electorate do not directly translate into the reorganization of party structures. The tendency to block political advancement by the already established political elite still persists. Traditional political parties are afraid of this new situation, which can significantly harm their interests. Impeding these changes may seem to be an obvious reaction, inscribed in the rules of political struggle [Żukiewicz 2011: 345]. However, the constant increase in tension between the demands and expectations of the electorate and the offer of these parties may indicate that the current balance of power will not last for long. Upcoming transformations cannot be avoided, however, attempts should be made to control them. For this reason, leaders of traditional political parties should decide on utilising such a mechanism for selecting leaders as it would not exclude them from the political space while at the same time be a guarantor of power.

Being part of the $21^{\text {st }}$ century, we have all witnessed and participated in the intensification of globalisation processes as well as the generational change and the popularisation of ideas related to the information
\end{abstract}


society. The significant increase in the importance of the phenomenon of mediatisation of politics causes a reversal of the hierarchy of attributes and predispositions which are desired by society [Schulz 2004: 87-101]. The image of political leaders on social media begins to outweigh their actual leadership skills. There is a danger that the new mechanism responsible for creating party structures will indeed facilitate the circulation of the elite, but unfortunately at the expense of the quality of potential leaders. That is why it is so important that the transformation process of the political power system proceeds as designed, and not in a chaotic manner, succumbing to bottom-up trends.

In addition, external factors of an international nature make it difficult to conduct research on the latest political phenomena. The changes currently occurring in society require new research perspectives and approaches. Traditional theories concerning the political system and the understanding of party structure may turn out to be insufficient.

Key words: situational leadership, political parties, political leadership

\section{INTRODUCTION}

In the available literature on the subject of leadership in political parties, researchers usually adopt concepts related to political power and leadership in the general dimension as a starting point. Bohdan Kaczmarek [2011: 51], Przemysław Żukiewicz [2011: 51] and Maciej Hartliński [2011: 47] define the general aspect of the concept of party leadership by focusing on a strong correlation of this phenomenon with the types and nature of leadership. In their typologies, there is a reference to the division of leadership, being a result of the nature of its activity, and distinguishes leadership as [Hartliński 2011: 46]:

- political, which is broadly understood to be leadership achieved within state institutions, which in this case are not only equated with political parties;

- religious, which can be equated with political activities (the case of political leaders who also happen to be spiritual leaders), but which are achieved more in terms of the Church rather than the State;

- business, whose operating environment should be a profitable company, but at the same time, not preclude an overlap with political leadership.

The above classification is one of the most popular as well as complicating issues related to political leadership [Bielski 1997: 68]. The current research discourse lacks a theory that would clearly define the boundaries of the functioning of political leadership as well as systematise the knowledge of the detailed aspect of leadership in political parties [Kanarski 2005: 121].

In addition, the following research scheme referred to in research on party leadership is Max Weber's theory as three types of authority: traditional, legal and charismatic [Wiatr 2008: 56-58]. This results in continuous duplication of an already established model. It is therefore difficult to adopt a more innovative and altogether different research perspective, as the already quoted theories set the direction of analysis. As a result of this, research perspectives can most often be found, which define the types and characteristics of party leadership directly through the personality traits of a given 
leader. Such definitions determine the way of later analysis, which only focuses on the study of individual biographies, specific behaviour and political actions [Żukiewicz 2011: 83-86]. Types of leaderships are determined by classifying the characteristics of leaders. In addition, these are usually features that do not relate to intra-party organization relations but are attributes forming a description of the external political image.

Furthermore, the above research trends are closely related to actual political leaders, which, in turn, cause multiplication of possible dimensions, ratios and levels of analysis. There is an important psychological aspect which, due to its complex nature, makes it much more difficult to reach the right conclusions. It is also worth paying attention to the fact that the reproduced typology is rooted in a given time with a set and existing political order. Its implementation into current political phenomena may not be possible.

In addition, social changes that concern the subject matter are new phenomena that have culminated in the last two years. The available Polish analysis concerning party leadership describes the problem in detail, from the beginning of 1989 through to 2011. However, there is no attempt to explicate the mechanisms which determined the elimination of party leaders from the past six years.

The theories presented by Max Weber, among others, are extremely valuable for political and sociological scientific achievements [Orzechowski 1984: 213]. Unfortunately, based on the definitions of leadership created years ago, only the already well-established schemes are reproduced and only previously tested and established hypotheses are confirmed. The changes that have occurred in society demand that a new look is taken at political leadership which have been achieved in the party leadership of democratic systems. This will be possible if the research perspective changes and ceases to look for a political dimension in all organizations and as a consequence political parties are treated as organizations.

\section{PARTY LEADERSHIP}

There are many problematic issues connected with the concept of party leadership. Due to the limitations related to the formal requirements of this article, it is not possible to present and explain all aspects related to party leadership. It is only possible to indicate some unsolvable contradictions resulting from top-down assumptions regarding the functioning of politics, the political system as well as the role of political parties and the politicians themselves.

As already mentioned previously party leadership is identified with a certain subcategory of political leadership. However, the terminology associated with these aspects has already been accurately presented in literature related to this subject. Therefore, it is possible to use a ready-made definition of political leadership by omitting conceptual origins. Political leadership, in particular, is a social process in which a member of the community voluntarily provides political support to another member of the community [Żukiewicz 2011: 73]. The act of support is the result of 
recognising a given individual who has the best chance of achieving specific and shared political goals as the leader. In the case of political leadership in political parties, it is believed that this process is similar and differs only in that it does not take place in the entire society but within a formal group that is a political party [Hartliński 2011: 214]. The presented definition still possesses a strong accent of an individual electoral act, which is based on a subjective evaluation of the candidate's traits. This results in further stages of the research being closely related to the image, operation and behaviour of a particular politician [Atamańczuk 2000: 97]. Therefore, if one wants to avoid duplication of already established schemes and theories, the political party should be treated as a simple organization that has specific features, structure as well as both internal and external participants. This is a narrow research approach that results in irradiating issues related to the definition of what is political and aspects related to the establishment of a border between what is political and private.

As a result, the subject of research is the political party itself, in which the process of emerging leadership, along with party elites, takes place. The law on political parties defines a party as: "a voluntary organization, appearing under a specific name and aiming to participate in public life through the exercise of democratic methods of influencing the shaping of state policy or the exercise of public authority" [Ustawa o partiach politycznych z dnia 27 czerwca 1997 r. (Law on political parties 1997: Article 1)]. In the Western democratic system, the standard is to define sovereignty as a nation that exercises its power by means of deputies elected in free, equal, direct and secret ballot election. Most often, members who succeed in elections are organised into specific party structures. The effect of such a political mechanism is the transfer of rights to state political parties [Schumpeter 2003: 269]. This, in effect, causes a conflict of interest. Authority, to political parties, is an autotelic value. The goal of political parties is to gain or retain power, which is understood as participation in the governing of the state. One of the paradoxes of democratic systems of government appears on this level. Due to the fact that goals pursued by a sovereign society are not the same as those of political parties which, by means of the system, have real authority in the state. The best solution for society would be the efficient selection of candidates for party leaders as well as the constant circulation of the political elite, which would effectively ensure the best electoral offer [Sobolewska-Myślik et al. 2008: 112]. On the other hand, it is in the interest of political parties which have been successful at least once to halt or even block the process of selecting new party leaders. Current party leaders are afraid of losing their position. This is the reason why the existing process of selecting party elites is so strongly institutionalised [Hartliński 2011: 261]. The party leader is usually the person who defeated the other opponents in the election. This could also be the individual, who for many years has been leading the way in an authoritarian manner. Such a person may be the founder of a party or the president or chairman of an organization whose position has been shaped by years of political activity. In both 
these cases, the process of choosing a party leader is undesirable, hampering possible levels of leadership initiative among other party members. Researchers who study the reality of political parties write frankly about the defective mechanism responsible for creating political elites. This, being something which consequently causes individuals who are not very prominent and who lack both elementary knowledge and skills, to appear in politics [Bichta 2010: 32].

In addition, the problematic aspect of the selection of party leadership is complicated even more when considering the influence of democratic ideas on the very way political parties are organised. Legislation of Western European countries requires that all political organizations are created and function in a democratic manner. For example, the Polish Law on political parties from 1997, in Article eight, requires that party activities be organised according to democratic principles. On the other hand, there is a conviction among experts of this subject that there is a need for a strong, codified hierarchy and charismatic leadership. The success of a political party, its existence on the political scene and its victory in elections are seen as simply being the unique qualities of a leader [Wiatr 2008: 196].

Likewise, possible electoral systems do not solve the problem of party leadership. In the proportional system, there is a greater threat of the occurrence of the harmful phenomenon of "partocracy", which as a consequence would contribute to the domination of the political space by a political party game. On the other hand, the majoritarian electoral system intensifies the personalisation of politics, significantly strengthening the essence of the function of a political leader [Sobolewska-Myślik et al. 2008: 113]. This, with the current mechanism of identifying party leaders, could have a detrimental effect on the political system.

In addition, significant changes taking place in society resulted in the departure from the $19^{\text {th }}$ century classification of mass parties. Contemporary political parties are characterised by a significantly smaller number of members. There is also a threat of "over-parliamentarisation" which is dependent on the functioning of major political parties in only the parliamentary space [Sobolewska-Myślik et al. 2008: 114]. Professional activities are being carried out in political parties, unfortunately with an increased dependence on resources and financing from the state budget. In addition, communication between the party and voters takes place via the media. Direct contact is not significant. The result is an incorrect selection mechanism which is based on the image provided by media instead of actual skills. As far as the arrangement between the party and its external environment is concerned, the most characteristic features of this relationship are the instability and lesser loyalty of the electorate.

In the party system described above, party leadership has little chance of development that would be satisfactory for both the electorate and members of political parties. With this type of party structure, only stagnation is possible, which is something that will not affect either mood or social expectations. Party leadership will be dominated by the authoritarian ruling style of the old elite. This being done in the process of selection due to fear of sudden change, individuals, whose governments 
are seasonal in nature, will be admitted to the leadership without the appropriate skills and predispositions. The solutions proposed by the political system are not satisfactory.

\section{BLACHARD’S SITUATIONAL LEADERSHIP MODEL}

The situational leadership model belongs to modern paradigms in research conducted on the phenomenon of leadership [Żukiewicz 2011: 53]. The prototype of this theory was created by Paul Hersey and Ken Blachard in 1968 [Dr. Paul Hersey 2012]. Thus, the beginnings of this innovative scientific approach dates back to the time of the behavioural revolution in the United States. The innovative research perspective proposed by Hersey and Blanchard is to stop searching for one perfect type of leadership. What is more is that the whole theory is formulated on the basis of a bold contestation that the ideal style of leadership does not exist and cannot exist in reality. Instead, American scientists propose the idea of situational leadership, which consists in creating several styles of leadership, appropriately suited to the stage of development of a given person [Blanchard, Johnson 2008: 11]. One of the main slogans accompanying the idea of situational leadership is as follows: "to achieve maximum results, the leadership should be adjusted to the stage of development of the person involved" [Blanchard 2007: 76]. Further on, Blanchard re-emphasizes the key point: "Each employee needs a different approach" [2007]. According to the authors of the situational leadership theory, the application of the presented model will contribute to the creation of effective organizations and will ensure an efficient mechanism for identifying talents as well as people who are ready to be promoted.

The situational leadership model presented in this article is already the next version after certain auctorial modifications, redefined by Blanchard himself. According to the author of the book The One Minute Manager, some of the original assumptions of the theory were wrong and could not be confirmed in later studies. For this reason, the theory needed to be updated. The main principle, however, remains unchanged. Whereas described individual stages of personal development undergo a certain reconstruction. Blanchard distinguishes four main styles of management, which should apply accordingly to the four stages of the development of the individual [Blanchard 2007: 77].

The initial stage of development of every new employee or member of a political party is the phase of being an enthusiastic novice. This is based on the fact that the individual lacks the right skills and experience, however, is full of enthusiasm and willingness to learn. During this period, the employee is dominated by an open and optimistic attitude towards acquiring a new scope of knowledge. Therefore, the most appropriate management style will be that of directing (S1) [Blanchard 2007: 78]. At this stage, the leader should give precise instructions and supervise the subordinate's 
function in their new role. This also involves teaching and showing an example of the required behaviour.

The next stage of development of the participant is in the adoption of an attitude of disappointment. The skills of such an employee are far greater, but the rhythm of work can cause feelings of frustration due to the difficulties of the tasks entrusted to him. The appropriate style in this case in that of coaching (S2) [Blanchard 2007: 79]. At this stage, the subordinate still needs plenty of support from the leader. However, the nature of the relationship is more mutual. The leader continues to give instructions and monitors the employee's actions, while simultaneously controlling the feedback. This sort of interaction is aimed at creating self-confidence by the subordinate and moving him to the next level of development.

After these introductory stages, he enters a phase where the apprentice feels competent yet cautious. Employees such as these already have the necessary skills and experience to properly perform their task. However, individuals may often feel insecure during such a situation. Individuals have an alternating sense of both enthusiasm and discouragement. In this situation, there is a need for the leader to show support towards employees (S3) [Blanchard 2007: 79]. This functions more on a cooperative basis rather than direct instructions. The desirable goal at this stage is to strengthen subordinates in the belief that they are the right individuals to perform the entrusted task. This is a necessary step in order for employees to become independent individuals without the need for the leader's approval.

This developmental path brings to a close the last stage of being an independent expert, regardless if the participant is in an enterprise or political party. This is a person not only characterised by learned skills but also by many years of experience. Due to his flexibility and competence towards such individuals, the leader can now apply task delegation (S4) [Blanchard 2007: 80]. In this case, employees assume full responsibility for their own work. This, however, is not treated as punishment but as a show of the leader's trust.

After approximation of the basic theses, the SLII leadership model may seem obvious. However, becoming the SLII management leader only seems easy. First of all, the situational leader must demonstrate the ability to diagnose the level of competence and commitment of his subordinates. Secondly, this must be a flexible person who is able to use different leadership styles for different types of people [Blanchard 2007: 86].

In addition, such a leader should have the ability to collaborate with the aim of achieving results. In the case of political parties, the last problem may prove to be the biggest requirement. To what extent will the political leader be able to give up his own interest in favour of the success of his political party?

Considering the above, the implementation of the situational leadership model according to Blanchard is not impossible to implement in the political environment. Naturally, we are dealing with a different understanding of values such as profit or the efficiency of action. Nevertheless, the SLII model does not threaten either the leader's position or the given party order. It maintains the accepted internal party hierarchy. At 
the same time, it favours the exploration of above-average individuals who are characterised by initiative and represent a certain readiness to adopt a more significant and responsible function.

\section{POPULAR STYLES OF LEADERSHIP}

The situational leadership model created by Blanchard is not only an ideal type of scheme. Thanks to this theory which consists of multiple elements, the proposed mechanism allows for multidimensional analysis as well as typical leadership styles. Moreover, some of the combinations of leadership styles presented are characteristic of behaviour in political parties. Leaders usually manage co-workers, limiting themselves to only utilising two types of leadership styles. Instead of correctly using all four categories and properly matching the type of style to the development stage of the subordinate individuals.

The first of the profiles is a combination of the S1 and S2 styles [Hersey et al. 2015: 200]. The result is a deformation of the coaching style. In this case, the leader cannot give up full control and decide to trust his employees. This sort of a leader is only convinced of his unique predispositions and skills. This is a profile that only works in crisis situations, or in the event of transformation or when introducing significant changes to the organization. Leaders who use this pattern are usually promoted employees who can not find themselves in the role of a managing person.

The most typical style for political party leaders who want to maintain their position at all costs is the profile consisting of the S1 and S3 styles [Hersey et al. 2015: 201]. This kind of leadership abuses both the power of the model as well as the power of punishment. Employees/party members, who do not act in accordance with the leader's vision, are punished and the directing method is applied to them, significantly limiting their ability to act. Whereas, conformists who express appreciation for the leader's actions are entrusted with more responsible tasks. However, this leadership profile is pernicious in which full development is not possible. In this case, every manifestation of individualism must be suppressed, and the recent favourite may fall back to the starting position. Leaders who are characterized by this style consider their subordinates to be lazy, unreliable and irresponsible. According to such leaders, the only effective mechanism is the system of penalties and rewards as well as close and constant control. Subordinates divide into two groups: the good ones who agree with him and the bad ones - those who have a different opinion.

Another combination of styles in which the individuals located at the bottom of the structure are exposed to the risk of manipulation is a combination of extreme types such as S1 and S4 [Hersey et al. 2015: 203]. This type of employee management occurs in organizations which possess a poorly defined purpose. The developmental opportunities which employees face are totally unachievable. This behaviour is typical of new leaders who are the owners or creators of a given organization. 
The attitude of the leader to subordinates is similar to the profile S1 and S3, only with this difference that members of the organization are divided not on the basis of sympathy and antipathy. The division is determined by their competence or lack thereof. In the case when the subordinate is considered as competent person, he is left to himself. There does not exist help from the leader, because he treats him as an independent member of the organization. If the subordinate does not have the appropriate skills, the leader uses the instructional style. This profile works only in crisis situations, when you need to make improvements in a short time. However, it completely prevents the development of both subordinates and the organization itself.

The next action profile is a combination of the S2 and S3 styles [Hersey et al. 2015: 204]. Such companies are considered to be "over-psychologised" and are subject to coaching trends. Leaders acting according to the combination of styles S2 and S3 may have difficulties with discipline in the organization. The problem may also be the introduction of novices in system structures. On the other hand, it is a profile considered to be the most secure pattern of leadership behaviour.

While the combination of S2 and S4 styles is typical for leaders who guarantee their sense of security by introducing principles of directives. Leaders who are characterized by the S2 and S4 profiles use S4 style occasionally, only in relation to trusted people styles [Hersey et al. 2015: 205]. Unfortunately, due to the shift from S2 style to S4 style, bypassing the S3 intermediate style, employees delegate tasks more in the penalty category than prizes. Such a leader's behaviour, according to them, is not a chance for development but a test that they can not cope with anyway.

The last option is the profile consisting of S3 and S4 styles [Hersey et al. 2015: 206]. It is more possible, for this profile to be present not so much in parties as in political groups, circles, clubs or commissions. These are situations where there is a small number of members and there is no recruitment of new ones.

The theory proposed by Blanchard is so flexible that it also presents a model which is ready to analyse the political space. This is a safe alternative to already well-established theories, which closely analyse the types of party leadership by means of their characteristics of a given policy and system determinants. The proposed four main types of management give the possibility of many combinations, which broadens the possibilities of research work.

\section{CONCLUSIONS}

Theories defining party leadership and presenting strong correlations of this process with political leadership further complicate the research problem. These introduce chaos to terminology and research, multiplying the types of possible aspects, dimensions, determinants as well as factors, by which the conceptualization of the phenomenon is accomplished [Avery 2009: 64]. Popular research perspectives on the subject of analysis, namely party leadership, only duplicate well-established 
schemes, bringing nothing new to scientific achievements. That is why it is so important to attempt a political analysis which would benefit from other interdisciplinary research paradigms.

The SLII process is suitable for selecting leadership as well as party elites. At the same time, it does not interfere, in the hierarchical order which is so valuable to the political system. The leader's function is still of utmost importance [Griffin 2004: 264]. It does not disturb the strong position of leadership or the tendency to personalise politics. On the contrary, political leaders who show that they can manage the party by using the situational leadership model would only consolidate their leadership position. The solution proposed by Blanchard, may be used in a theory of political parties.

The current mechanism of party leadership only slows down the emergence of a bottom-up initiative. The inner-party struggle becomes the norm, and, in turn, becomes more important than the struggle between the parties. Leaders are afraid to allow potential competitors to compete. This style of behaviour reflects the combination of style S1 and S3. A perfect example of this is the leadership of Jarosław Kaczyński in the Law and Justice party. His leadership was created during the crisis, caused by the catastrophe in Smoleńsk. From then on, Kaczyński maintains the atmosphere and narrative of the war. Thanks to this, it is easier to lead him in the party and gain the support of the electorate. Kaczyński currently has no competition in the party. $\mathrm{He}$ treats people who trust in using mechanisms belonging to the $\mathrm{S} 3$ style. Unfortunately, they are not people who are distinguished by their competence and experience. The leader of Law and Justice values conformists more. In addition, in the case of the smallest manifestation of "rebellion", this person falls in the party hierarchy to the ordinary member, to whom the S1 style belongs. Based on the level of popularity and the results of the parliamentary elections, the traditional leadership, accompanied by the narrative of crisis and chaos, works well in the political environment.

In the case of Paweł Kukiz's leadership, he is perceived as an authentic leader through emotional and simple speech. On the other hand, full power and decision-making in the party belong to him. He is a leader whose behavior resembles the S2 and S3 profiles. Style S2 is even used for new members of the party, it is enough to agree with the general postulates of Kukiz. In leadership behavior there is a lack of introducing new members, instructing how to behave in basic relationships. There is freedom at lower levels. Kukiz's leadership behavior lacks awareness and knowledge about the political space, which gives the impression that the leadership is dispersed. It is also difficult to distinguish members who are in a close circle of trusted ones. Kukiz does not use his organization to delegate tasks. Members who have gained more independence are removed from the organization (for example, Piotr Liroy Marzec).

An interesting example is also Janusz Korwin-Mikke style of leadership according to the Blanchard typology. He is a leader who notoriously applies the S1 management style. He has undivided power in the party. He makes the final decisions on his own without taking into account the opinions of other members. On the Polish 
political scene, people who come from the Korwin environment usually quote his statements, confirming their correctness and legitimacy. On the other hand, there is a lot of freedom in the Internet space for interpreting the vision of Korwin-Mikke. Anyone can join the organization with the application available online. It is enough to agree with the ideology presented by Korwin and pay the party contributions. Taking into account the activity of members and supporters of the party Wolność on the Internet, it can be concluded that in the case of shaping relationships in a virtual space, tasks on such a large scale are carried out thanks to delegation. In addition, the management of youths who belong to the party is based on the S4 model. Unfortunately, in the case of Korwin-Mikke, the combination of styles S1 and S4 is quite harmful. Because Korwin-Mikke uses the S4 style only in the case of a dimension which, according to him, does not matter much. That is why members of the organization have long functioned only in a certain mirage of independence. Behavior in the political reality shows that Korwin-Mikke does not allow anyone to report on a higher level of situational leadership. If the personal conflict, takes the nature of an unsolvable problem, in which he would have to give up part of the authority, then he gives up such a relationship and creates a new party.

The issues presented in this article are only a general outline of the topic which relates to the application of the situational leadership model in political parties. There is clearly a need for a more thorough and extensive case study. Unfortunately, the formal limitations of this text only allowed for brief indications of selected aspects.

\section{BIBLIOGRAPHY}

Atamańczuk, K. 2000. Jednostka, grupa, przywództwo w teorii i praktyce zarządzania, Wydawnictwo Olsztyńskiej Wyższej Szkoły Informatyki i Zarządzania im. prof. Tadeusza Kotarbińskiego, Olsztyn. Avery, G. 2009. Przywództwo w organizacji, Polskie Wydawnictwo Ekonomiczne, Warszawa.

Bichta, T. 2010. Typy i style przywództwa politycznego. Przywództwo w partiach politycznych w Polsce,

[in:] Władza i przywództwo polityczne w demokracji, E. Nowak, D. Litwin-Lewandowska (eds.), Wydawnictwo Uniwersytetu Marii Curie-Skłodowskiej, Lublin.

Bielski, M. 1997. Organizacje, istota, struktury, procesy, Wydawnictwo Uniwersytetu Łódzkiego, Łódź. Blanchard, K. 2007. Przywództwo wyższego stopnia: Blanchard o przywództwie i tworzeniu efektywnych organizacji, Wydawnictwo Naukowe PWN, Warszawa.

Blanchard, K., Johnson, S. 2008. Jednominutowy menedżer, Wydawnictwo Medium, Warszawa.

Dr. Paul Hersey, 2012, http://obits.dignitymemorial.com/dignity-memorial/obituary.aspx?n=Paul-Hersey \&lc $=4234 \& \mathrm{pid}=161837015 \& \mathrm{mid}=5348521$ (access: 06.12.2017).

Dudek, A. 2016. Historia polityczna polski 1989-2015, Społeczny Instytut Wydawniczy Znak, Kraków. Griffin, R.W. 2004. Podstawy zarzadzania organizacjami, Wydawnictwo Naukowe PWN, Warszawa. Hartliński, M. 2011. Przywództwo partyjne w Polsce, Wydawnictwo Adam Marszałek, Torun.

Hersey, P., Blanchard, K., Johnson, D. 2015. Management of Organizational Behavior. Leading Human Resources, Pearson, Boston.

Kaczmarek, B. 2011. Przywództwo polityczne a przywództwo organizacyjne, [in:] Przywództwo polityczne, T. Bodio (ed.), Dom Wydawniczy i Handlowy Elipsa, Warszawa. 
Kanarski, L. 2005. Przywództwo we współczesnych organizacjach, Dom Wydawniczy i Handlowy Elipsa, Warszawa.

Kim jesteśmy?, https://nowoczesna.org/kim-jestesmy/ (access: 05.12.2017).

Konstytucja Rzeczypospolitej Polskiej z dnia 2 kwietnia 1997 r., (Dz.U. 1997, nr 78 poz. 483).

O stowarzyszeniu - władze krajowe i okręgowe, http://ruchkukiza.pl/stowarzyszenie/o-stowarzyszeniu/ (access: 05.12.2017).

Orzechowski, M. 1984. Polityka władza panowanie w teorii Maxa Webera, Państwowe Wydawnictwo Naukowe, Warszawa.

Schulz, W. 2004. Reconstructing Mediatization as an Analytical Concept, "European Journal of Communication", vol. 19, pp. 87-101, DOI: https://doi.org/10.1177/0267323104040696.

Schumpeter, J. 2003. Capitalism, Socialism and Democracy, Perennial, London.

Sobolewska-Myślik, K., Kosowska-Gąstoł, B., Borowiec, P. 2008. Przywództwo w polskich partiach politycznych $w$ świetle analizy struktury i charakteru naczelnych władz partyjnych, [in:] Partie polityczne - przywództwo partyjne, J. Sielski, M. Czerwiński (eds.), Wydawnictwo Adam Marszałek, Toruń.

Ustawa o partiach politycznych z dnia 27 czerwca 1997 r., (Dz.U. 1997, nr 98 poz. 604).

Wiatr, J.J. 2008. Przywództwo polityczne. Studium politologiczne, Wydawnictwo Wyższej Szkoły Humanistyczno-Ekonomicznej, Łódź.

Żukiewicz, P. 2011. Przywództwo polityczne. Teoria i praktyka, Difin, Warszawa.

\section{BIOGRAPHY}

Natalia Stręk, MA in political science and a graduate in human resources management at the Jagiellonian University. $\mathrm{PhD}$ student in the field of political science at the Institute of Political Science and International Relations of the Jagiellonian University. Participant in the international project "Polish and Israeli pre service teachers: The healing process", concerning Polish-Jewish relations. E-mail: natalia. strek@uj.edu.pl 